\title{
Relationship between Antioxidant Potential and Oxidative Damage to Lipids, Proteins and DNA in Aged Rats
}

\author{
M. SIVOŇOVÁ ${ }^{1}$, Z. TATARKOVÁ ${ }^{1}$, Z. ĎURAČKOVÁ ${ }^{2}$, D. DOBROTA ${ }^{1}$, \\ J. LEHOTSKÝ ${ }^{1}$, T. MATÁKOVÁ ${ }^{1}$, P. KAPLÁN ${ }^{1}$ \\ ${ }^{1}$ Department of Medical Biochemistry, Comenius University, Jessenius Faculty of Medicine, Martin \\ and ${ }^{2}$ Department of Medical Chemistry, Biochemistry and Clinical Chemistry, Comenius \\ University, Faculty of Medicine, Bratislava, Slovakia
}

Received August 18, 2006

Accepted October 7, 2006

On-line available November 6, 2006

\begin{abstract}
Summary
Oxidative stress has been implicated to play a major role in aging and age-related diseases. In the present study, we investigated the effects of aging on the total antioxidant capacity, uric acid, lipid peroxidation, total sulfhydryl group content and damage to DNA in adult (6 months), old (15 months) and senescent (26 months) male Wistar rats. The antioxidant capacity, determined by phycoerythrin-based TRAP method (total peroxyl radical-trapping potential) was significantly decreased in the plasma and myocardium of old and senescent rats, whereas plasma level of uric acid was elevated in 26-month-old rats. Age-related decline in plasma and heart antioxidant capacity was accompanied by a significant loss in total sulfhydryl group content, increased lipid peroxidation and higher DNA damage in lymphocytes. Correlations between TRAP and oxidative damage to lipids, proteins and DNA suggest that the decline in antioxidant status may play an important role in age-related accumulation of cell damage caused by reactive oxygen species.
\end{abstract}

Key words

Aging $\bullet$ Antioxidant potential $\bullet$ Lipid peroxidation $\bullet$ Comet assay $\bullet$ Total sulfhydryl groups

\section{Introduction}

The free radical theory of aging proposes that agedependent deterioration in cell function is related to accumulation of molecular oxidative damage, caused by reactive oxygen or nitrogen species (ROS/RNS). An increase in production of reactive radicals, particularly as a result of mitochondrial dysfunction, has been recognized as a major cause of oxidative stress (Kalous and Drahota 1996, Van Remmen and Richardson 2001). However, age-associated alterations in the antioxidant status could also contribute to increased oxidative stress in aging.

The concentration of free radicals during normal oxygen metabolism is controlled by various antioxidants and a balance exists between prooxidant and antioxidant processes (Golden et al. 2002). Changes in antioxidants capacities such as hydrophilic radical scavengers (ascorbate, urate and glutathione), lipophilic radical scavengers (tocopherols, carotenoids), metal chelators and antioxidant enzymes like superoxide dismutase, catalase and glutathione peroxidase activities have been 
demonstrated in aging (Bejma et al. 2000, Asha Devi et al. 2003, Sobočanec et al. 2005, KrajčovičováKudláčková et al. 2006, Saičić et al. 2006). However, selective measurement of the antioxidant capacity does not provide relevant information on the overall antioxidant status. Moreover, total antioxidant capacity is determined not only by concentration/activity of individual antioxidants but also by their synergistic action. Therefore, various methods have been developed to measure the total antioxidant capacity (Prior and Cao 1999). Several studies have explored the effect of aging on total antioxidant capacity of plasma and tissues. They showed reduced (Facino et al. 1999, Kim et al. 2002, Quiles et al. 2004, Rodrigues Siqueira et al. 2005) or unchanged (Nakamura and Omaye 2004) antioxidant defence.

It is widely accepted that lipid peroxidation is an important and probably primary event in the progress of several diseases as well as degenerative processes associated with aging (Kohen and Nyska 2002, Szweda et al. 2003). The products of lipid peroxidation (mainly in the presence of transition metal ions) initiate further free radical chain reactions and can cause oxidative damage to proteins and DNA (Nakamura and Omaye 2004, Stocker and Keaney 2004, Vassalle et al. 2004). Accumulation of oxidatively damaged DNA, as a result of lipid peroxidation or direct effect of ROS/RNS, could lead to a decreased mRNA expression and protein production and decline in physiological functions during aging. Even minor lesions can have profound biological consequences unless the base excision-repair pathway removes them. The levels of DNA damage and its repair capacity have been widely considered to be factors closely related to aging (Umegaki et al. 2001, Gedik et al. 2005).

The aim of our study was 1) to determine total antioxidant capacity of plasma and heart homogenate during aging, 2) to determine plasma concentrations of uric acid, and 3) to study the relationship between the total antioxidant potential and markers of lipid, protein and DNA oxidation in the plasma and heart homogenates of adult (6 months), old (15 months) and senescent (26 months) male Wistar rats.

\section{Methods}

\section{Chemicals}

2,2'-diazobis(2-amidinopropane) dihydrochloride (AAPH) and 6-OH-2,5,6,7-tetramethyl-2-carboxylic acid
(Trolox) were obtained from Aldrich (USA). All other chemicals used in this study were purchased from Sigma (USA). Glass microscope slides used were non-fully frosted.

\section{Animals}

Twenty-one male Wistar rats (breeding station of Slovak Academy of Sciences, Dobrá Voda, Slovakia), where divided into three groups: 1) adult (6-month-old, 330-380 g), 2) old (15-month-old, 400-490 g) and 3 ) senescent (26-month-old, 430-530 g). The animals were housed in wire-bottomed cages in a temperaturecontrolled room $\left(22^{\circ} \mathrm{C}\right)$ with a 12-h light/dark cycle. Food and distilled water were provided ad libitum. This study was approved by the Ethical Committee, State Veterinary Administration of the Slovak Republic and performed in accordance with the guidelines of the National Institute of Health for the care and use of laboratory animals.

\section{Preparation of plasma and tissue homogenates}

The animals, anesthetized with $2 \%$ halothane, were sacrificed by decapitation. Blood and hearts were immediately removed. The hearts were washed three times with physiological solution and stored at $-80{ }^{\circ} \mathrm{C}$ until used. Blood was collected into heparinized tubes. Aliquots of whole blood were immediately centrifuged at $12000 \times g$ for $3 \mathrm{~min}$, kept in an ice-bath and rapidly assayed for TRAP. A portion $(0.3 \mathrm{ml})$ of whole blood was retained for comet assay. The rest of blood was used for preparation of plasma by centrifugation at $2000 \times g$ for $15 \mathrm{~min}$.

Frozen powdered hearts (about $1 \mathrm{~g}$ ) were thawed in 10 volumes of ice-cold homogenization buffer (30 mmol/1 $\quad \mathrm{KH}_{2} \mathrm{PO}_{4}, \quad 5 \mathrm{mmol} / 1 \quad$ EDTA, $0.3 \mathrm{~mol} / 1$ saccharose, $\mathrm{pH} 7.0$ ) with 0.3 mmol/l PMSF (phenylmethylsulphonylfluoride) and homogenized three times for $10 \mathrm{~s}$ at $25000 \mathrm{rpm}$ with ULTRA-Turrax T25 homogenizer. Aliquots of the homogenate were stored at $-80{ }^{\circ} \mathrm{C}$ and were used for determination of TRAP, TBARS and protein content. The protein concentration was determined by the method of Lowry et al. (1951) using bovine serum albumin as standard.

\section{Total radical-trapping antioxidant potential (TRAP} assay)

The trapping radical antioxidant potential (TRAP) was determined by a modified method of Ghiselli et al. 
(1995). This method is based on the protection afforded by plasma antioxidants against the decay of R-phycoerythrin (R-PE) fluorescence emission during a controlled peroxidation reaction initiated by AAPH. Reaction mixture $(2 \mathrm{ml})$ contained $7.5 \mu \mathrm{l}$-PE (final concentration $\left.1.5 \times 10^{-8} \mathrm{~mol} / \mathrm{l}\right)$, rat plasma $(8 \mu \mathrm{l})$ or heart homogenate $(50 \mu \mathrm{g}$ proteins) in $75 \mathrm{mmol} / 1$ phosphate buffer, $\mathrm{pH} 7.0$ and was preincubated at $37^{\circ} \mathrm{C}$ for $5 \mathrm{~min}$ in $10 \mathrm{~mm}$ fluorimeter cells. Adding AAPH to a final concentration of $4.0 \mathrm{mmol} / \mathrm{l}$ started the oxidation reaction. The decay of R-PE fluorescence at $575 \mathrm{~nm}$ (10 nm slit width) was monitored by excitation at $495 \mathrm{~nm}$ (10 nm slit width) every $5 \mathrm{~min}$ for $120 \mathrm{~min}$ on a spectrofluorometer RF-540 (Shimadzu), equipped with a thermostatically controlled cell-holder. The results were standardized using $30 \mu \mathrm{l}$ of $120 \mu \mathrm{mol} / 1$ Trolox a watersoluble analog of $\alpha$-tocopherol. TRAP values were calculated from the length of the lag-phase due to the sample compared with that of Trolox and were expressed as $\mu \mathrm{mol}$ of Trolox $/ 1$ of plasma or as $\mu \mathrm{mol} / \mathrm{mg}$ of proteins.

Plasma uric acid levels were measured using the commercial Uric acid liquicolor kit (Human, Sigma, St. Louis, MO).

\section{Determination of total sulfhydryl group content}

The content of total sulfhydryl groups in plasma and heart homogenate was determined using DTNB (5.5'dithiobis[2-nitrobenzoic acid]) (Hu 1994, Tatarková et al. 2005). The content of protein sulfhydryls was calculated using molar extinction coefficient of $1.36 \times 10^{4} \mathrm{~mol} / \mathrm{l} / \mathrm{cm}$. Total sulfhydryl group content values were expressed in $\mu \mathrm{mol} / \mathrm{mg}$ proteins.

\section{TBARS determination}

The degree of lipid peroxidation was assayed by estimating the thiobarbituric acid reactive substances (TBARS) by spectrophotometric method. Samples (50 $\mu 1$ of plasma or heart homogenate) were deproteinized by adding $1 \mathrm{ml}$ of $14 \%$ trichloroacetic acid and $1 \mathrm{ml}$ of $0.6 \%$ thiobarbituric acid. The mixture was heated in a water bath for $30 \mathrm{~min}$ at $80{ }^{\circ} \mathrm{C}$ to complete the reaction and then cooled on ice for $5 \mathrm{~min}$. After centrifugation $\left(2000 \times g, 10 \mathrm{~min}, 4{ }^{\circ} \mathrm{C}\right)$ the absorbance of the colored product (TBARS) was measured at $535 \mathrm{~nm}$ with a Spectrophotometer LKB Ultraspec III (Pharmacia). The concentration of TBARS was calculated using the molar extinction coefficient of malondialdehyde $\left(1.56 \times 10^{5} \mathrm{~mol} / \mathrm{l} / \mathrm{cm}\right)$. All TBARS concentrations were expressed in $\mathrm{nmol} / \mathrm{mg}$ of protein.

\section{Oxidative damage to DNA - single cell gel}

electrophoresis (SCGE) - comet assay

Isolation of lymphocytes: $300 \mu \mathrm{l}$ of fresh blood were mixed with $1 \mathrm{ml}$ of PBS (0.1 mol/1, pH 7.4) and incubated on ice for $30 \mathrm{~min}$. After incubation, it was layered onto $100 \mu \mathrm{l}$ of Histopaque 1083 (on ice) and centrifuged at $200 \times g, 4{ }^{\circ} \mathrm{C}$, for $5 \mathrm{~min}$. The layer of lymphocytes was collected into $500 \mu \mathrm{l}$ of PBS and centrifuged again under the same conditions. Sediment (lymphocytes) was used for comet assay. The amount of lymphocytes was sufficient for 4 gels $\left(2 \times 10^{4}\right.$ cells in each gel).

Comet assay: DNA single strand breaks were measured using alkaline comet assay (Gedik et al. 1992, Collins et al. 1997). Glass microscope slides were frosted with $1 \%$ normal melting point agarose (type I- A) prepared in deionised water. Lymphocytes (from $300 \mu \mathrm{l}$ of blood) were resuspended in $400 \mu \mathrm{l}$ of $0.8 \%$ low melting point agarose (type VII A) in PBS at $37{ }^{\circ} \mathrm{C}$ and pipetted onto a frosted microscope slide precoated with $100 \mu \mathrm{l}$ of $1 \%$ normal melting point agarose. Slides with layers of lymphocytes in agarose were incubated at $4{ }^{\circ} \mathrm{C}$ for $10 \mathrm{~min}$ and then immersed in lysis solution $(2.5 \mathrm{~mol} / 1$ $\mathrm{NaCl}, 100 \mathrm{mmol} / 1 \mathrm{Na}_{2}$ EDTA, $10 \mathrm{mmol} / 1$ Tris, $1 \%$ Triton, $\mathrm{pH}$ 10) for one hour to remove cellular membranes. After lysis, slides were placed in a horizontal electrophoresis tank containing electrophoretic solution (1 $\mathrm{mmol} / \mathrm{l}$ $\mathrm{Na}_{2}$ EDTA, $300 \mathrm{mmol} / \mathrm{l} \mathrm{NaOH}$, pH 13) at $4{ }^{\circ} \mathrm{C}$ for $40 \mathrm{~min}$ (DNA unwinding). Electrophoresis was performed in the same solution at $25 \mathrm{~V}, 300 \mathrm{~mA}, 4{ }^{\circ} \mathrm{C}$, for $30 \mathrm{~min}$. The slides were washed three times for $5 \mathrm{~min}$ at $4{ }^{\circ} \mathrm{C}$ with neutralizing buffer $(0.4 \mathrm{mmol} / \mathrm{l}$ Tris, $\mathrm{pH} 7.5)$ before staining with $20 \mu \mathrm{l}$ 4',6-diamidine-2-phenylindole dihydrochloride - DAPI $(2 \mu \mathrm{g} / \mathrm{ml})$.

Visual scoring: Each slide was viewed by fluorescence microscopy (Olympus BX 41, UK) and the degree of damage in nucleotides was assessed visually. Each of 100 nucleotides or comets was assigned a score from 0 to 4 , depending on the fraction of DNA pulled out into the tail under the influence of the electric field (Collins et al. 1996).

Results were expressed as the total damage to DNA (TD) in rats with aging. Total damage was calculated as $\mathrm{TD}=\Sigma$ (class of damage $\times$ number of cells in this class). 
a)

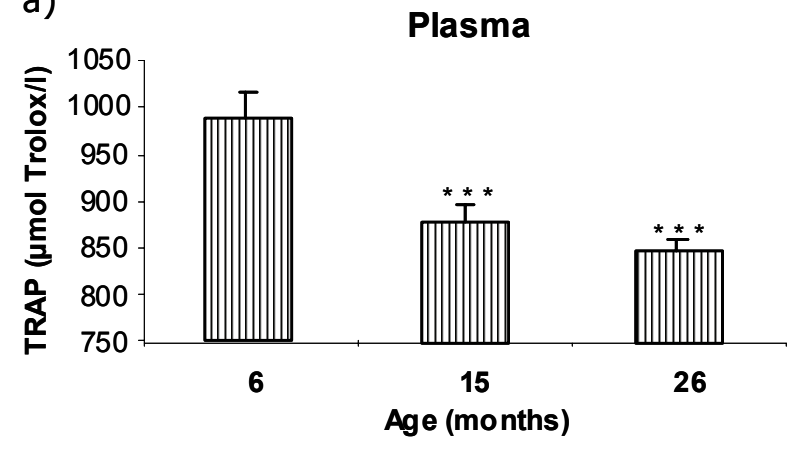

b)

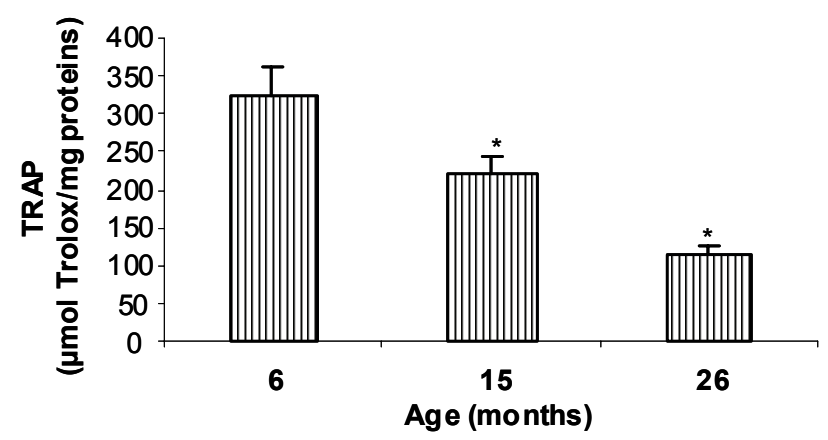

Fig. 1. Changes in the plasma (a) and heart homogenate (b) total radical-trapping antioxidant potential (TRAP) during aging. The production of peroxyl radicals in plasma was initiated by adding AAPH at a final concentration of $4.0 \mathrm{mmol} / \mathrm{l}$. Results are presented as mean \pm S.E.M. for $\mathrm{n}=7$. $* \mathrm{p}<0.05$, $* * \mathrm{p}<0.01$, significantly different as compared to 6-month-old rats.

\section{Statistics}

The data are reported as mean \pm standard error of the mean. The differences between adult, old and senescent rats were analysed with Student's t-test. $\mathrm{P}<0.05$ values were considered statistically significant.

\section{Results}

The total antioxidant capacities measured as TRAP in blood plasma of different age groups are shown in Figure 1a. There was a significant decrease in the TRAP values for 15-month-old and 26-month-old rats in comparison with the 6-month-old group. TRAP values in heart homogenates were decreased in old and senescent rats in comparison to adult rats (Fig. 1b).

To determine the effect of aging on oxidative modification of proteins changes were studied in total sulfhydryl groups, which play an important role in the catalysis and regulation of antioxidant reactions. Total plasma sulfhydryl group values significantly declined with age from $0.104 \pm 0.004 \mu \mathrm{mol} / \mathrm{mg}$ proteins for adult

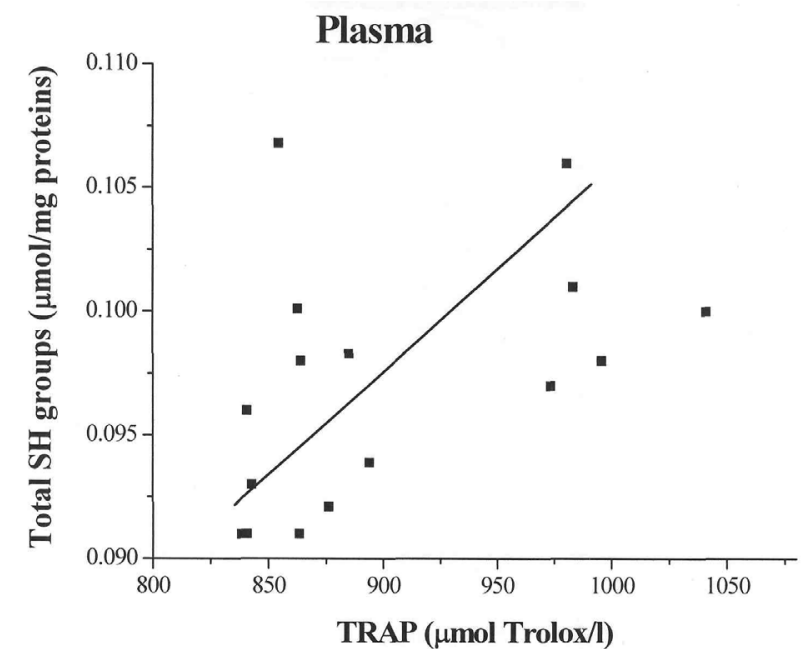

Fig. 2. Correlation between the plasma total radical-trapping antioxidant potential (TRAP) and total sulfhydryl group content in $6-, 15-$ and 26-month-old rats $(y=6 \mathrm{E}-05 \mathrm{x}+0.0442, r=0.51$, $\mathrm{n}=21, \mathrm{p}<0.05)$.

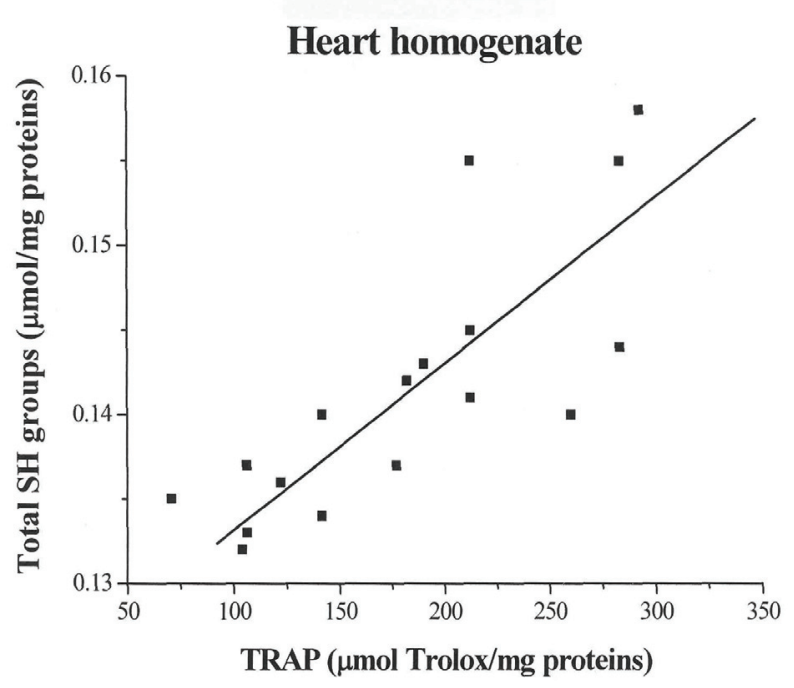

Fig. 3. Correlation between the heart homogenate total radicaltrapping antioxidant potential (TRAP) and total sulfhydryl group content in 6-, 15- and 26-month-old rats $(y=9 \mathrm{E}-5 \mathrm{x}+0.1262$, $r=0.85, n=21, p<0.001)$.

rats to $0.096 \pm 0.006$ and $0.093 \pm 0.001 \mu \mathrm{mol} / \mathrm{mg}$ proteins $(p<0.05)$ for old and senescent rats, respectively. The total levels of sulfhydryl groups in heart homogenates also significantly declined with age for old $(0.142 \pm 0.003 \mu \mathrm{mol} / \mathrm{mg}$ proteins, $\mathrm{p}<0.01)$ and senescent rats $(0.136 \pm 0.003 \mu \mathrm{mol} / \mathrm{mg}$ proteins, $\mathrm{p}<0.001)$ in comparison with adult rats $(0.157 \pm 0.002 \mu \mathrm{mol} / \mathrm{mg}$ proteins). As demonstrated in Figures 2 and 3, the alterations in plasma and myocardial total sulfhydryl group content correlated well with TRAP values.

In order to evaluate the contribution of uric acid to 


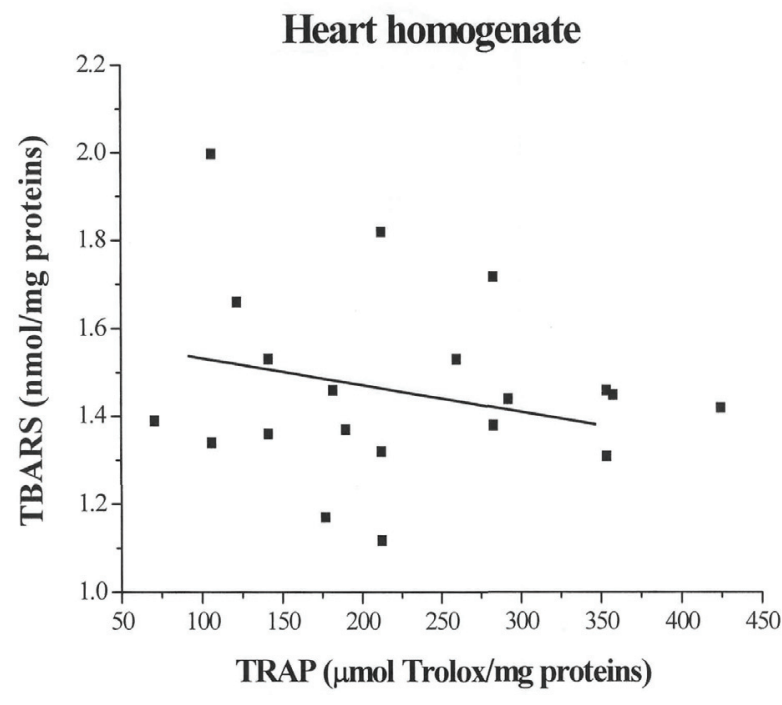

Fig. 4. Correlation between the heart homogenate total radicaltrapping antioxidant potential (TRAP) and thiobarbituric acid reactive substances (TBARS) in 6-, 15- and 26-month-old rats $(y=-0.0002 x+1.5116, r=0.11, n=21, N S)$.

TRAP, the plasma level of this antioxidant of metabolic origin was measured. The plasma uric acid level in 15-month-old rats was not altered $(29.1 \pm 2 \mu \mathrm{mol} / 1)$, whereas plasma from 26-month-old rats showed a significant increase of this parameter $(40.6 \pm 2.6 \mu \mathrm{mol} / 1$, $\mathrm{p}<0.01)$ when compared to 6-month-old rats (27.8 $\pm 2.5 \mu \mathrm{mol} / \mathrm{l})$.

To determine the age-dependent effect on lipid peroxidation, TBARS was measured in plasma and heart homogenates. The plasma levels of TBARS increase with age from $0.104 \pm 0.008 \mathrm{nmol} / \mathrm{mg}$ proteins in adult groups to $0.112 \pm 0.007$ and $0.145 \pm 0.008 \mathrm{nmol} / \mathrm{mg}$ proteins $(\mathrm{p}<0.05)$ in the old and senescent group, respectively. In contrast, TBARS levels in heart homogenates were only slightly increased by aging, but the TBARS content tended to correlate inversely with total antioxidant capacity (Fig. 4).

The effects of aging on oxygen-radical-generated DNA damage in rat lymphocytes have been investigated using the comet assay, which allows the detection of DNA alterations of diverse kinds, such as double-strand breaks, single-strand breaks, alkali-labile sites, incomplete repair sites, and cross-links. Statistically significant increases in DNA damage $(\mathrm{p}<0.001)$ were observed in old $(134.7 \pm 4.8)$ and senescent $(166.3 \pm 5.7)$

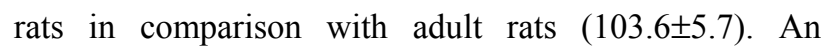
increase of oxidative damage to DNA negatively correlated with the antioxidant potential in rat plasma (Fig. 5).

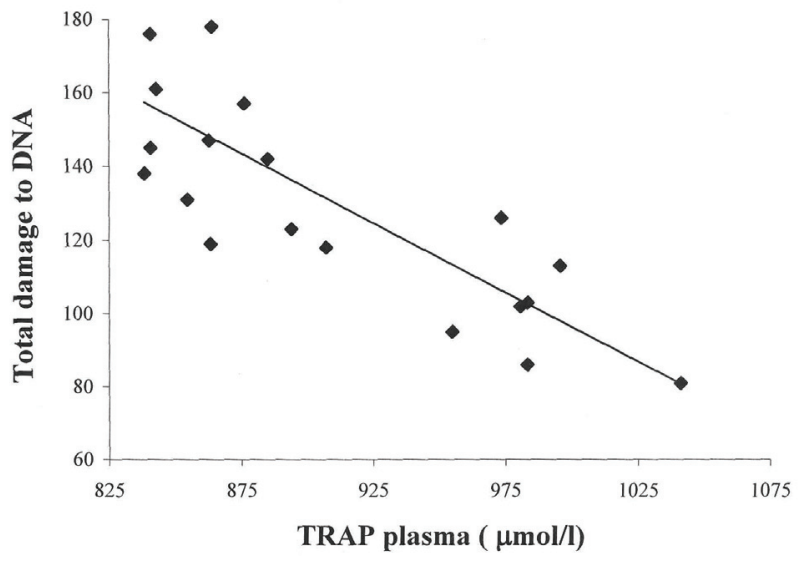

Fig. 5. Correlation between the plasma total radical-trapping antioxidant potential (TRAP) and the total damage to DNA in rat lymphocytes. in 6-, 15- and 26-month-old rats $(y=-0.3773 x+$ 473.63, $r=0.80, n=21, p<0.001)$.

\section{Discussion}

The total radical trapping potential and overall antioxidant potential of rat plasma and heart homogenate was determined by the TRAP assay by using AAPH, a peroxyl radical generator. This assay measures antioxidants located in both the hydrophilic and lipophilic compartments of the plasma (Ghiselli et al. 1995) or tissue homogenates (Evelson et al. 2001). Relative contribution of the total antioxidant capacity to agerelated oxidative stress is not well defined. While some studies demonstrated that total antioxidant capacity of plasma decreases in aged rats (Facino et al. 1999, Kim et al. 2002), others showed that it is unchanged (Nakamura and Omaye 2004). Our data support the view that aging is associated with a loss antioxidant capacity of plasma. Moreover, age-related decline in total antioxidant capacity was also observed in the heart homogenates. Previous studies have demonstrated a low antioxidant capacity in the rat heart (Cao et al. 1996, Evelson et al. 2001), but an effect of aging was not observed (Cao et al. 1996). Age-related decrease in the antioxidant status of the heart, which was observed in our study, is consistent with the previous reports showing depletion of main antioxidants: vitamin C (van der Loo et al. 2003), $\alpha$-tocopherol (Kamzalov and Sohal 2004), vitamin A (van der Loo et al. 2004), reduced glutathione and decreased activities of antioxidant enzymes (Kakarla et al. 2005) in aged rat heart. Despite of significant reduction in the total antioxidant capacity, myocardial content of TBARS was elevated to a lesser extent. These findings agree with previous studies showing less pronounced increase of myocardial TBARS levels during aging (Boucher et al. 
1998, Bejma et al. 2000). On the other hand, myocardial sulfhydryl group content was significantly decreased with aging, indicating that protein oxidation might play a more important role in myocardial aging than lipid peroxidation.

The changes in concentrations of plasma antioxidants during a peroxyl radical attack suggest that the first line of defense is provided by plasma sulfhydryl groups, even urate being spared during the initial stages of the reaction (Ghiselli et al. 2000). Several studies have shown an age-dependent reduction in the total levels of sulfhydryl groups, which play a prominent role not only in antioxidant reactions but also in reactions of catalysis, regulation, electron transport and those preserving the correct structure of proteins (Hernanz et al. 2000, Thomas and Mallis 2001). Iciek et al. (2004) have shown that the efficiency of S-thiolation (conjugation of protein thiols with non-protein thiols) as a mechanism of antioxidant defense decreases with age, which leads to an increased risk of irreversible oxidation of sulfhydryl groups of plasma proteins. These findings are consistent with our results showing an age-dependent reduction in total sulfhydryl group in the rat plasma and could reflect their oxidation in the aqueous phase of plasma. It is important to note that the age-dependent changes in TRAP values positively correlated with total sulfhydryl group in rat plasma. This indicates a close association between the plasma antioxidant status and the total sulfhydryl group content.

Uric acid is a powerful water-soluble antioxidant. We have measured uric acid level since it is more determined by metabolic and nutritional influences rather than by altered oxidative stress. In contrast to the previously reported decrease in plasma urate concentration in 20-month-old rats (Facino et al. 1999), we have observed a significant rise in uric acid levels in 26-month-old rats when compared to 6- and 15-monthold rats. From these results, it is evident that the decrease in plasma total antioxidant capacity observed in our study is not overestimated due to changes in uric acid levels.

Accumulation of free radical-mediated DNA damage has been implicated in the mechanism of aging and age-related diseases, such as cancer cardiovascular diseases and neurodegenerative diseases. Age-related accumulation of 8-hydroxy-deoxyguanosine adducts (8-OHdG), markers of oxidative DNA damage, have been detected in various tissues, including liver, brain, and heart (Quiles et al. 2004, Wolf et al. 2005). Wolf et al. (2005) have suggested that the 8 -OHdG levels in peripheral lymphocytes may serve as an index of agerelated oxidative DNA damage of the whole organism. The present study also shows that the level of oxidatively damaged DNA in rat lymphocytes increases with age. It also demonstrates the correlation between DNA damage and the total antioxidant capacity and suggests that the loss in antioxidant defense is an important factor contributing to DNA mutations associated with aging.

In conclusion, our study demonstrates an agerelated decrease in total antioxidant capacity of the rat plasma and myocardium and indicates that this decrease may be involved in the mechanisms of free radicalinduced damage to lipids, proteins and DNA during aging.

\section{Acknowledgements}

This work was supported by grants UK/38/2005, VEGA 1/2263/05 and APVT-51-027404 from the Ministry of Education and Science of the Slovak Republic.

\section{References}

ASHA DEVI S, PRATHIMA S, SUBRAMANYAM MV: Dietary vitamin E and physical exercise. II. Antioxidant status and lipofuscin-like substances in aging rat heart. Exp Gerontol 38: 291-297, 2003.

BEJMA J, RAMIRES P, LI LL: Free radical generation and oxidative stress with ageing and exercise: differential effects in the myocardium and liver. Acta Physiol Scand 169: 343-351, 2000.

BOUCHER F, TANGUY S, BESSE S, TRESALLET N, FAVIER A, DE LEIRIS J: Age-dependent changes in myocardial susceptibility to zero flow ischemia and reperfusion in isolated perfused rat hearts: relation to antioxidant status. Mech Ageing Dev 103: 301-316, 1998.

CAO G, GIOVANONI M, PRIOR RL: Antioxidant capacity decreases during growth but not aging in rat serum and brain. Arch Gerontol Geriatr 22: 27-37, 1996.

COLLINS A, DUŠINSKÁ M, GEDIK CM, ŠTETINA R: Oxidative damage to DNA: do we have a reliable biomarker? Environ Health Perspect 104: 465-469, 1996. 
COLLINS A, DUŠINSKÁ M, FRANKLIN M, SOMOROVSKA M, PETROVSKA H, DUTHIE S, FILLION L, PANAYIOTIDIS M, RAŠLOVÁ K, VAUGHAN N: Comet assay in human biomonitoring studies: reliability, validation, and applications. Environ Mol Mutagen 30: 139-146, 1997.

EVELSON P, TRAVACIO M, REPETTO M, ESCOBAR J, LLESUY S, LISSI EA: Evaluation of total reactive antioxidant potential (TRAP) of tissue homogenates and their cytosols. Arch Biochem Biophys 15: 261-266, 2001.

FACINO RM, CARINI M, ALDINI G, BERTI F, ROSSONI G, BOMBARDELLI E, MORAZZONI P: Diet enriched with procyanidins enhances antioxidant activity and reduces myocardial post-ischaemic damage in rats. Life Sci 64: 627-642, 1999.

GEDIK CM, EWEN SWB, COLLINS AR: Single-cell gel electrophoresis applied to the analysis of UV-C damage and its repair in human cells. Int J Radiat Biol 62: 313-320, 1992.

GEDIK CM, GRANT G, MORRICE PC, WOOD SGG, COLLINS AR: Effects of age and dietary restriction on oxidative DNA damage, antioxidant protection and DNA repair in rats. Eur J Nutr 44: 263-272, 2005.

GHISELLI A, SERAFINI M, MAIANI G, AZZINI E, FERRO-LUZZI A: A fluorescence-based method for measuring total plasma antioxidant capability. Free Radic Biol Med 18: 29-36, 1995.

GHISELLI A, SERAFINI M, NATELLA F, SCACCINI C: Total antioxidant capacity as a tool to assess redox status: critical view and experimental data. Free Radic Biol Med 29: 1106-1114, 2000.

GOLDEN TR, HINERFELD DA, MELOV S: Oxidative stress and aging: beyond correlation. Aging Cell 1: 117-123, 2002.

HERNANZ A, FERNÁNDEZ-VIVANCOS E, MONTIEL C, VAZQUEZ JJ, ARNALICH F: Changes in the intracellular homocysteine and glutathione content associated with aging. Life Sci 67: 1317-1324, 2000.

HU ML: Measurement of protein thiol groups and glutathione in plasma. Methods Enzymol 233: 380-385, 1994.

ICIEK M, CHWATKO G, LORENC-KOCI E, BALD E, WLODEK L: Plasma levels of total, free and protein bound thiols as well as sulfane sulfur in different age groups of rats. Acta Biochim Pol 51: 815-824, 2004.

KAKARLA P, VADLURI G, REDDY KS, LEEUWENBURGH C: Vulnerability of the mid aged rat myocardium to the age-induced oxidative stress: influence of exercise training on antioxidant defense system. Free Radic Res 39: 1211-1217, 2005.

KALOUS M, DRAHOTA Z: The role of mitochondria in aging. Physiol Res 45: 351-359, 1996.

KAMZALOV S, SOHAL RS: Effect of age and caloric restriction on coenzyme Q and alpha-tocopherol levels in the rat. Exp Gerontol 39: 1199-1205, 2004.

KIM JW, NO JK, IKENO Y, YU BP, CHOI JS, YOKOZAWA T, CHUNG HY: Age-related changes in redox status of rat serum. Arch Gerontol Geriatr 34: 9-17, 2002.

KOHEN R, NYSKA A: Oxidation of biological systems: oxidative stress phenomena, antioxidants, redox reactions, and methods for their quantification. Toxicol Pathol 30: 620-650, 2002.

KRAJČOVIČOVÁ-KUDLÁČKOVÁ M, DUŠINSKÁ M, VALACHOVIČOVÁ M, BLAŽÍČEK P, PAUKOVÁ V: Products of DNA, protein and lipid oxidative damage in relation to vitamin $\mathrm{C}$ plasma concentration. Physiol Res 55: 227-231, 2006.

LOWRY OH, ROSEBROUGH NJ, FARR AL, RANDALL RJ: Protein measurement with the Folin phenol reagent. J Biol Chem 193: 265-275, 1951.

NAKAMURA YK, OMAYE ST: Age-related changes of serum lipoprotein oxidation in rats. Life Sci 23: 1265-1275, 2004.

PRIOR RL, CAO G: In vivo total antioxidant capacity: comparison of different analytical methods. Free Radic Biol Med 27: 1173-1181, 1999.

QUILES JL, OCHOA JL, RAMIREZ-TORTOSA C, BATTINO M, HUERTAS JR, MARTÍN Y, MATAIX J: Dietary fat type (virgin olive vs. sunflower oils) affects age-related changes in DNA double-strand-breaks, antioxidant capacity and blood lipids in rats. Exp Gerontol 39: 1189-1198, 2004.

RODRIGUES SIQUEIRA I, FOCHESATTA C, da SILVA TORRES IL, DALMAZ C, ALEXANDRE NETTO C: Aging affects oxidative state in hippocampus, hypothalamus and adrenal glands of Wistar rats. Life Sci 78: 271-278, 2005. 
SAIČIĆ ZS, MIJALKOVIĆ DN, NIKOLIĆ AL, BLAGOJEVIĆ DP, SPASIĆ MB: Effect of thyroxine on antioxidant defense system in the liver of rats of different age. Physiol Res 55: 561-568, 2006.

SOBOČANEC S, BALOG T, ŠVERKO V, MAROTTI T: Met-enkephalin modulation of age-related changes in red cell antioxidant status. Physiol Res 54: 97-104, 2005.

STOCKER R, KEANEY JF: Role of oxidative modifications in atherosclerosis. Physiol Rev 84: 1381-1478, 2004.

SZWEDA PA, CAMOUSE M, LUNBERG KC, OBERLEY TD, SZWEDA LI: Aging, lipofuscin formation, and free radical-mediated inhibition of cellular proteolytic systems. Ageing Res Rev 2: 383-405, 2003.

TATARKOVÁ Z, KAPLÁN P, MATEJOVIČOVÁ M, LEHOTSKÝ J, DOBROTA D, FLAMENG W: Effect of ischemia and reperfusion on protein oxidation in isolated rabbit hearts. Physiol Res 54: 185-191, 2005.

THOMAS JA, MALLIS RJ: Aging and oxidation of reactive protein sulfhydryls. Exp Gerontol 36: 1519-1526, 2001.

UMEGAKI K, HASHIMOTO M, YAMASAKI H, FUJII Y, YOSHIMURA M, SUGISAWA A, SHINOZUKA K: Docosahexaenoic acid supplementation-increased oxidative damage in bone marrow DNA in aged rats and its relation to antioxidant vitamins. Free Radic Res 34: 427-435, 2001.

VAN DER LOO B, BACHSCHMID M, SPITZER V, BREY L, ULLRICH V, LÜSCHER TF: Decreased plasma and tissue levels of vitamin $\mathrm{C}$ in a rat model of aging: implications for antioxidative defense. Biochem Biophys Res Commun 303: 483-487, 2003.

VAN DER LOO B, LABUGGER R, AEBISCHER CP, BACHSCHMID M, SPITZER V, KILO J, ALTWEGG L, ULLRICH V, LÜSCHER TF: Age-related changes of vitamin A status. J Cardiovasc Pharmacol 43: 26-30, 2004.

VAN REMMEN H, RICHARDSON A: Oxidative damage to mitochondria and aging. Exp Gerontol 36: 957-968, 2001.

VASSALLE C, PETROZZI L, BOTTO N, ANDREASSI MG, ZUCCHELLI GC: Oxidative stress and its association with coronary artery disease and different atherogenic risk factors. J Intern Med 256: 308-315, 2004.

WOLF FI, FASANELLA S, TEDESCO B, CAVALLINI G, DONATI A, BERGAMINI E, CITTADINI A: Peripheral lymphocyte 8-OHdG levels correlate with age-associated increase of tissue oxidative DNA damage in Sprague-Dawley rats. Protective effects of caloric restriction. Exp Gerontol 40: 181-188, 2005.

\section{Corresponding author}

M. Sivoňová, Department of Medical Biochemistry, Jessenius Faculty of Medicine, Comenius University, Malá hora 4, 03601 Martin, Slovak Republic. Fax: +421 43 4136770. E-mail: sivonova@jfmed.uniba.sk 